\title{
A Review on Chemical Synthesis Process of Platinum Nanoparticles
}

\author{
Md. Aminul Islam, M. Anwarul Kabir Bhuiya, M. Saidul Islam
}

Department of Materials Science and Engineering, University of Rajshahi, Bangladesh

\begin{abstract}
Nanoparticles are key components in the advancement of future energy technologies; thus, strategies for preparing nanoparticles in large volume by techniques that are costeffective are required. In the substitution of fossil-fuels by renewable energy resources, nanometersized particles play a key role for synthesizing energy vectors from varying and heterogeneous biomass feedstocks. They are extensively used in reformers for the production of hydrogen from solid, liquid, or gaseous energy carriers. Catalyst activities depend critically on their size-dependent properties. Nanoparticles are further indispensable as electrocatalysts in fuel cells and other electrochemical converters. The desire to increase the activity per unit area, and decrease the necessary amount of the expensive catalytic standard, It is clear that performance and commercialization of fuel cells depend on electrode materials performance. The application of pt nanomaterials as an electrode in the field of fuel cell has become a new, growing area of interest in recent years. We review chemical process for synthesis of pt nanoparticles. Recent developments in syntheses process of pure \& mixed platinum nanoparticles has briefly reviewed specifically for applications in fuel cells. As the physicochemical properties of noble-metal nanostructures are strongly dependent upon shape and size, the development of reliable synthesis methods for the production of nanocrystals with well-defined size and morphology have been discussed briefly. The role of nanostructured supports for the nanoparticles, such as ordered mesoporous carbon, dendrimer have also discussed. And size of the nanoparticles obtained in deferent process and their temperature dependence has also discussed briefly.
\end{abstract}

Keywords: Platinum nanoparticles; Supporting materials; Chemical process of synthesis; Growth control

\section{INTRODUCTION}

The chemical method is relatively easy and inexpensive, with some difficulties to place and align the resulting nanostructures in desired configurations or patterns. $\mathrm{Pt}$ metal 
nanoparticles have been usually prepared by impregnation and reduction of $\mathrm{Pt}$ metal precursors in a micro porous support. In this paper, we will discuss recent advances made in the synthesis of platinum nanoparticles using chemical synthetic procedures on supporting materials.

General rout of chemical synthesis of Pt. nanoparticles is as:

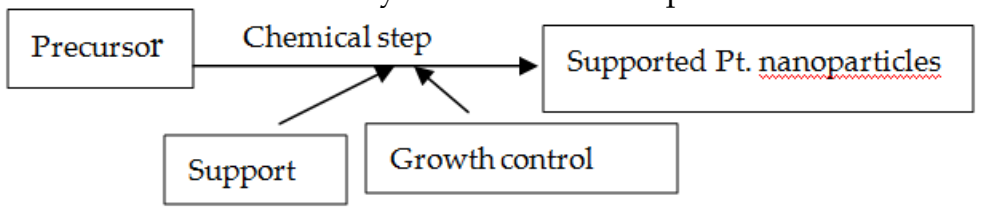

Fig. 1 Chemical synthesis process of supported metal nanoparticles.

In the synthesis process, the pt metal precursor, either in an ionic or a molecular state is taken. Chemical changes are initiated to convert the precursor to pt metal atoms by the reducing agent, these metal atoms then merge into suitable supported materials/or stabilizer to form nanoparticles. For example in chemical reduction, $\mathrm{H}_{2} \mathrm{PtCl}_{6}$ is reduced by $\mathrm{NaBH}_{4}$ (Park and et.al. 2002) or Zn (Jiang and et.al.2003) to give rise to platinum nanoparticles;

\section{$\mathrm{H}_{2} \mathrm{PtCl}_{6}+\mathrm{NaBH}_{4} \longrightarrow \mathrm{Pt}+$ Other reaction product.}

Particle growth is usually confined by the presence of a confining support or a protection agent/stabilizer, Supported and size-controlled nanoparticles are then formed. For example in surfactant-stabilized colloidal method, in which $\mathrm{H}_{2} \mathrm{PtCl}_{6}$ was employed as the precursors of $\mathrm{Pt}$ nanoparticles, and zwitterionic surfactant 3-(N, Ndimethyldodecylammonio) propanesulfonate (SB 12) as the stabilizer and methanol as the reductant (Li and Hsing 2006).

\section{Precursor}

The common precursor used in platinum nanoparticles synthesis is $\mathrm{H}_{2} \mathrm{PtCl}_{6}$. The precursor is usually dissolved in an aqueous or organic liquid phase. The chemical step to change the dissolved metal precursor to the solid metal is usually effected by the introduction of a reducing agent. Other chemical steps such as decomposition, displacement, or electrochemical reactions are also possible. In addition to initiation by physical mixing, the chemical step can be activated by radiolytic (Belapurkar and et. al.2001) sono-chemical (Chen and et. al. 2003) or electrochemical means (Zoval and et. al. 1998). In addition to the chemical steps, many additional physical steps are required between the initial precursor state to the final supported state in a working electrode (Chan and et. al. 2004).

In situations of mixed metal nanoparticles the different reactivities of two types of precursors, e.g. $\mathrm{RuCl}_{3}$ and $\mathrm{H}_{2} \mathrm{PtCl}_{6}$ (Maiyalagan 2009, Yang and et. al. 2003, William and et. al. 2002 ) are usually used. Sometimes $\left\{\mathrm{Pt}\left(\mathrm{NH}_{3}\right)_{2}\left(\mathrm{NO}_{2}\right)_{2}, \mathrm{Ru}_{3}(\mathrm{CO})_{12}, \mathrm{RuNO}\left(\mathrm{NO}_{3}\right)\right\}($ Takasu and et. al. 2000), $\left\{\mathrm{Na}_{6} \mathrm{Pt}\left(\mathrm{SO}_{3}\right)_{4}, \mathrm{Na}_{6} \mathrm{Ru}\left(\mathrm{SO}_{3}\right)_{4}\right\}$ (Friedrich and et. al. 2002), $\left\{\mathrm{PtCl}_{2}\right.$ and $\left.\mathrm{RuCl}_{3}\right\}(\mathrm{Choi}$ and et. al. 2003) etc. various complex precursors have been also used. Now we will discuss about supporting materials usually used in synthesis process of platinum nanoparticles.

\section{SUPPORTING MATERIALS}

The support for the metal nanoparticles turns out to be as important as the nanoparticles for providing their dispersion and stability. It also provides electrical conductivity when used as 
electrode for catalyst. The need for electrical conductivity has ruled out conventional catalyst supports such as molecular sieves and alumina (Rajesh and et. al. 2002).

In addition to electrical conductivity, supporting materials must have some important properties such as high surface area, hydrophobicity, morphology, porosity, corrosion resistance etc. for the choice as a good catalyst support. So that low surface area single crystal metals and graphite are undesirable as support materials. Based on these considerations, carbon is the best catalyst support material for low temperature fuel cells. Carbon black (Takasu and et. al. 2000), and activated carbons have been extensively used as catalyst supports, with Vulcan 72 being the most representative.( Yang and et. al. 2003, William and et. al. 2002, Dubau et. al. 2003). In the last decade, a number of new synthetic carbons with various mesostructures and nanostructures have been reported. These include carbon nanotubes, aerogel carbon and mesocarbon with or without a high degree of order(Yu and et. al. 2002). Our focus is on several new types of synthetic carbon materials as mixed metal nanoparticle catalysts in fuel cell electrodes. The family of carbon nanotubes is the most well known synthetic porous carbon. These carbon nanotubes may be semiconducting or metallic in behavior. In the synthesizing of carbon nanotubes, these require purification from amorphous carbon. In addition, uniform loading of metal into sub nanometer scale nanotubes is not a simple task. Metal nanoparticles are often adhered to the outside of nanotubes or in the inter-tubular space.

Aligned and monodispersed carbon nanotubes loaded with $\mathrm{Pt}, \mathrm{Pt}-\mathrm{Ru}$ abd Pt-WO3 nanoparticles showed good electrochemical activity for oxygen reduction and methanol oxidation which is evaluated through cyclic voltammetry (Rajesh and et al. 2002). At the same time the performance of multi wall carbon nanotube loade with $\mathrm{Pt}$ also was investigated and $\mathrm{Pt}$ loaded multi wall carbon nanotubes at $900 \mathrm{C}$ shows a better Oxidation for methanol ( $\mathrm{Li}$ and et al. 2003). Some researchers have walked around the loading method of noble metals (Ye and et al. 2003, Yu and et al. 1998). But we will lock up our discuss in a brief about mesocarbon and dendrimer which are hugely used as a supporting materials.

\section{MESOCARBON}

A recent important development is the synthesis of ordered carbon structures with tunable pore sizes on the order of 2 to $50 \mathrm{~nm}$ (mesopores). The mesopores are expected to offer better mass-transfer properties compared to carbon nanotubes (Warren and et al. 2008). The ordered mesoporous carbon is synthesized by a templating procedure starting with highly ordered mesoporous silica as shown schematically in Fig.2

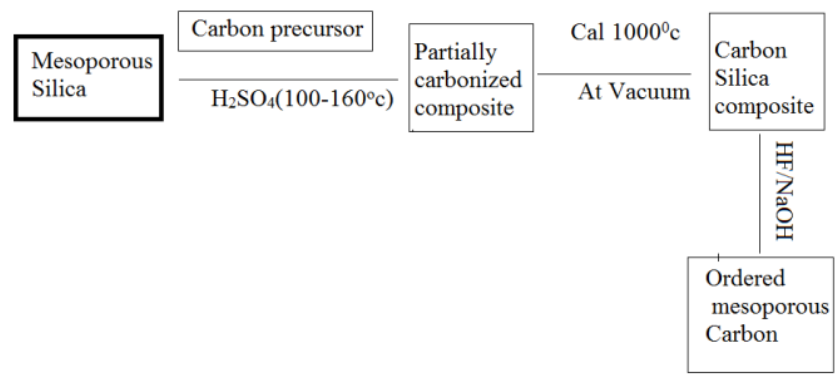

Fig. 2 Show the mesoporous silica preparation process 
A variety of ordered but amorphous silica porous structures can be synthesized. Carbon replicas are made by filling up the porous silica with a carbon source such as sucrose and allowing carbonization to take place at an elevated temperature about $1000^{\circ} \mathrm{C}$. The silica template can be removed by dissolution in $\mathrm{HF}$ or $\mathrm{NaOH}$. By using different silica templates corresponding different carbon structures can be made.

\section{DENDRIMER}

Dendrimers are good candidates for preparing metal nanoparticles because they can act as structurally and well-defined templates and robust stabilizers. Dendrimers are highly branched macromolecules and generally described to have a structure of spherical shape with a high degree of symmetry. In the field of catalysis, the hope is that dendrimer catalysts will retain the benefits of homogeneous catalysts (high activity, high selectivity, good reproducibility, accessibility of the metal site and so on) and, unlike most other polymeric species, they will be readily recoverable after reaction. In principle, dendrimer is one of the most promising candidates that can meet the needs for an ideal catalyst: persistent and controllable nanoscale dimensions, chemically reactive surface, favorable configuration in which all the active sites would always be exposed towards the reaction mixture so that they are easily accessible to migrating reactants, and soluble but can be easily recovered by filtration. These properties, or some combination of them, are what makes dendrimers so useful for application in catalysis. Dendrimers have also been considered as new types of host for accommodation of guest molecules by virtue of their three-dimensional structure having interior void space, and hence various metal nanoparticles have been successfully prepared using dendrimer as a template (Kim and et al. 2004). The driving force for guest encapsulation within dendrimers can be based on electrostatic interactions, complexation reactions, steric confinement, various types of weaker forces (van der Waals, hydrogen bonding, hydrophobic force, etc.), and their combinations. For example: Polyamidoamine (PAMAM) dendrimers, in particular, have been used as nano reactors with effective nanoparticle stabilization. In addition, encapsulated nanoparticles surfaces are accessible to substrates so that catalytic reactions can be carried out (Knecht and et al. 2004). The electrocatalytically activity for oxygen reduction of PAMAM dendrimer encapsulated $\mathrm{Pt}$ nanoparticles and $\mathrm{Pt}-\mathrm{Pd}$ bimetallic nanoaparticles are studied (Ye and Crooks 2007). The dendrimer-encapsulation process of platinum nanoparticles also examined through the supported on carbon fiber (Ledesma and et et al. 2008) and nitrogendoped CNT as electrodes for oxygen reduction (Vijayaraghavan and Stevenson 2007). (Maiyalagan 2009) makes use of the fourth generation amine-terminated PAMAM dendrimers $\left(\mathrm{G}_{4}-\mathrm{NH}_{2}\right)$ to anchor on the functionalized carbon nanofiber $(\mathrm{CNF})$ as a substrate and then encapsulate $\mathrm{Pt}-\mathrm{Ru}$ nanoparticles on dendrimers for the better dispersion of the electrode, which exhibited very good catalytic activity. Now we will focus our discussion on the growth process of platinum nanoparticles.

\section{Growth Control}

It is the most important step for nano particles synthesis. During the chemical step, metal atoms formed will aggregate to form a nucleus. Nuclei that grow beyond a critical size will be stable, but a mechanism is needed to curb the growth of particles and to achieve a narrow size distribution. Different growth control mechanisms and strategies are used in the different types of nanoparticle synthesis. On base of growth control mechanism chemical process can be classified as (A) Colloidal method, (B)Microemulsion methods, (C) Impregnation method. 
Asia Pacific Journal of Energy and Environment, Volume 1, No 2 (2014)

In the colloidal method, aggregation of nanoparticles is prevented either by electrostatic hindrance or the addition of a protecting agent, which will adhere onto the surface of the nanoparticles. In the microemulsion methods, surfactants are added and chemical reaction and mass-transfer processes are confined within the microdroplets engulfed by the surfactant molecules. A simpler strategy in the impregnation method is the early addition of the microporous support before the start of the chemical step. The support then acts as the confining medium to restrict reaction, diffusion, and aggregation processes.

Table 1 Reports of chemical methods for synthesis of supported pure pt. metal nanoparticles with their characterizations.

\begin{tabular}{|c|c|c|c|c|c|c|}
\hline $\begin{array}{c}\text { Nano } \\
\text { particles }\end{array}$ & Size & Support/Loading & $\begin{array}{l}\text { Preparation } \\
\text { Method }\end{array}$ & Precursor & Characterization & Reference \\
\hline $\mathrm{Pt}$ & $2-3 \mathrm{~nm}$ & Vulcan XC-72R 20-60\% & Radiolytic synthesis & $\mathrm{H} 2 \mathrm{PtCl} 6$ & TEM & Gratiet and et al. 1998 \\
\hline $\mathrm{Pt}$ & $2.9 \mathrm{~nm}$ & Vulcan XC-72R $40 \%$ & $\begin{array}{c}\text { Reduction by ethylene glycol } \\
\text { at } 1300 \mathrm{c}\end{array}$ & $\mathrm{H} 2 \mathrm{PtCl} 6$ & $\begin{array}{l}\text { TEMTEM, CO- } \\
\text { Chemisorption }\end{array}$ & Zhou and et al. 2003 \\
\hline $\mathrm{Pt}$ & $9 \mathrm{~nm}$ & & Reduction by sodium borohydride & $\mathrm{H} 2 \mathrm{PtCl} 6$ & XRD, XPS, SEM & Chen and and et al. 2001 \\
\hline $\mathrm{Pt}$ & $3.5-13 \mathrm{~nm}$ & Vulcan XC-72R 10-50\% & Reduction by formaldehyde & $\mathrm{H} 2 \mathrm{PtCl} 6$ & TEM & Umeda and et al. 2003 \\
\hline $\mathrm{Pt}$ & $2.5 \mathrm{~nm}$ & Carbonised SBA15 20-50\% & $\begin{array}{c}\text { Impregnation } \mathrm{H} 2 \text { reduction } \\
\text { at } 300 \mathrm{uC}\end{array}$ & $\mathrm{H} 2 \mathrm{PtCl} 6$ & TEM, BET & Joo and et al. 2001 \\
\hline $\mathrm{Pt}$ & $3-5 \mathrm{~nm}$ & $\begin{array}{l}\text { Mesoporous carbon } \\
\text { microbeads }\end{array}$ & Liquid-phase reduction & $\mathrm{H} 2 \mathrm{PtCl} 6$ & SEM, XRD & Liu and et al. 2002 \\
\hline $\mathrm{Pt}$ & $7.1 \mathrm{~nm}$ & $\begin{array}{c}\text { Carbon nanotubes by CVD } \\
\text { with alumina membrane as } \\
\text { the template }\end{array}$ & $\begin{array}{c}\text { Impregnation } \mathrm{H} 2 \text { reduction } \\
\text { at } 580 \mathrm{uC}\end{array}$ & $\mathrm{H} 2 \mathrm{PtCl} 6$ & TEM, SEM & Che and et al. 1998 \\
\hline $\mathrm{Pt}$ & $1.2 \mathrm{~nm}$ & $\begin{array}{c}\text { Template carbonisation of } \\
\text { polypyrrole on a alumina } \\
\text { membrane }\end{array}$ & $\begin{array}{c}\text { Impregnation } \mathrm{H} 2 \text { reduction } \\
\text { at } 550 \mathrm{uC}\end{array}$ & $\mathrm{H} 2 \mathrm{PtCl} 6$ & SEM, XPS, HRTEM & Rajesh and et al. 2002 \\
\hline $\mathrm{Pt}$ & $2-5 \mathrm{~nm}$ & $\begin{array}{c}\text { Multiwalled carbon } \\
\text { nanotube }\end{array}$ & Liquid-phase reduction & $\mathrm{H} 2 \mathrm{PtCl} 6$ & HRTEM, XRD & $\mathrm{Li}$ and et al. 2003 \\
\hline $\mathrm{Pt}$ & $\begin{array}{c}2.6- \\
3.7 \mathrm{~nm}\end{array}$ & & $\begin{array}{c}\text { Reduction by aqueous } \\
\text { alcohol in the presence of } \\
\text { polymeric stabilizer protector), }\end{array}$ & (H2PtCl6.nH2O) & TEM,XRD & Wang and et al. 2009 \\
\hline $\mathrm{Pt}$ & $\begin{array}{c}3 \cdot 6 \pm 0 \cdot 6 \\
\mathrm{~nm}\end{array}$ & & $\begin{array}{c}\text { Thermolysis in hexadecylamine } \\
\text { (HDA) at } 210^{\circ} \mathrm{C} \text { under } \\
\text { argon atmosphere }\end{array}$ & \begin{tabular}{|c|}
$\mathrm{Pt} 2(\mu-$ \\
$\mathrm{OR}) 2(\mathrm{C} 8 \mathrm{H} 12 \mathrm{OMe})$ \\
2] $(\mathrm{R}=\mathrm{Me}$ or $\mathrm{Ac})$ \\
\end{tabular} & $\begin{array}{c}\text { XRD, EDAX and } \\
\text { TEM }\end{array}$ & Ghavale and et al. 2009 \\
\hline $\mathrm{Pt}$ & $2-5 \mathrm{~nm}$ & & $\begin{array}{c}\text { ethanolic reduction stabilized by } \\
\text { poly(N-vinyl-2-pyrrolidone) (PVP) } \\
\text { in ionic liquids }\end{array}$ & $\mathrm{H} 2 \mathrm{PtCl} 6.6 \mathrm{H} 2 \mathrm{O}$ & (HRTEM) & Mu and et al. 2004 \\
\hline $\mathrm{Pt}$ & $10 \mathrm{~nm}$ & $\begin{array}{c}\text { Vulcan XC-72 modified by } \\
\text { hydrogen } \\
\text { molybdenum bronze } \\
(\mathrm{HxMoO}, 0 \leq \mathrm{x} \leq 2)\end{array}$ & Reduction by formaldehyde & $\begin{array}{l}\text { Solution of } \\
\mathrm{H} 2 \mathrm{PtCl} 6 \text {, }\end{array}$ & SEM, XRD & Xiang and et al. 2010 \\
\hline $\mathrm{Pt}$ & $2-4 \mathrm{~nm}$ & $\begin{array}{l}\text { Multi-walled carbon } \\
\text { nanotubes (MWNTs }\end{array}$ & \begin{tabular}{|c|} 
Reduction by ethylene \\
glycol \& sodium \\
citrate as the coordination reagent \\
and stabilizer,
\end{tabular} & $\mathrm{H} 2 \mathrm{PtCl} 6$ & TEM, XRD & $\mathrm{Li}$ and Zhang 2008 \\
\hline $\mathrm{Pt}$ & $\sim 9 \mathrm{~nm}$ & & $\begin{array}{l}\text { Modified polyol process with the } \\
\text { addition of silver ions }\end{array}$ & $\mathrm{H} 2 \mathrm{PtCl} 6.6 \mathrm{H} 2 \mathrm{O}$, & TEM, HRTEM & Rioux and et al. 2006 \\
\hline
\end{tabular}

Table 2 Reports of chemical methods for synthesis of supported mixed Pt. metal nanoparticles with their characterizations.

\begin{tabular}{|c|c|c|c|c|c|c|}
\hline \begin{tabular}{|c|} 
Nano \\
particles
\end{tabular} & Size & Support/Loading & $\begin{array}{c}\text { Preparation } \\
\text { Method }\end{array}$ & Precursor & Characterization & References \\
\hline Pt-Ru & $2.6 \mathrm{~nm}$ & $\begin{array}{c}\text { Functionalized carbon } \\
\text { nanofibers }(\mathrm{CNF})\end{array}$ & Reduction by $\mathrm{NaBH} 4$ & $\mathrm{H}_{2} \mathrm{PtCl}_{6} \& \mathrm{RuCl}_{3}$ & $\begin{array}{l}\text { SEM, XRD, } \\
\text { TEM }\end{array}$ & Maiyalagan 2 \\
\hline $\mathrm{Pt}_{3} \mathrm{Ru}$ & $\begin{array}{c}1.5 \pm 0.5 \\
\mathrm{~nm}\end{array}$ & Vulcan XC-72,40\% Pt & $\begin{array}{c}\text { Impregnation } \mathrm{H} 2 \text { reduction } \\
\text { at } 120 \mathrm{OC}\end{array}$ & $\mathrm{H}_{2} \mathrm{PtCl}_{6}, \mathrm{RuCl}_{3}$ & $\begin{array}{c}\text { HRTEM, XRD, } \\
\text { EDAX, } \\
\text { TGA/DTA }\end{array}$ & \begin{tabular}{|c|} 
Yang and et al. \\
2003
\end{tabular} \\
\hline $\mathrm{Pt}_{\mathrm{x}} \mathrm{Ru}_{\mathrm{y}}$ & $2.7-3.9 \mathrm{~nm}$ & Carbon black & $\begin{array}{c}\text { Thermal decomposition } \\
\text { under } \mathrm{H}_{2}-\mathrm{N}_{2}\end{array}$ & $\begin{array}{c}\mathrm{Pt}\left(\mathrm{NH}_{3}\right)_{2}\left(\mathrm{NO}_{2}\right)_{2,} \mathrm{Ru}_{3}(\mathrm{CO})_{12} \\
\mathrm{RuNO}\left(\mathrm{NO}_{3}\right)_{\mathrm{x}}\end{array}$ & $\begin{array}{c}\text { HRSEM, BET, } \\
\text { HRTEM }\end{array}$ & \begin{tabular}{|c|} 
Takasu and et al. \\
2000
\end{tabular} \\
\hline PtRu & $3-15 \mathrm{~nm}$ & Vulcan XC-72 10-90\% & $\mathrm{H} 2$ reduction & $\begin{array}{l}\mathrm{Na}_{6} \mathrm{Pt}\left(\mathrm{SO}_{3}\right)_{4} \\
\mathrm{Na}_{6} \mathrm{Ru}\left(\mathrm{SO}_{3}\right)_{4}\end{array}$ & HRTEM, XRD,TEM & $\begin{array}{c}\text { Friedrich and et } \\
\text { al. } 2002\end{array}$ \\
\hline $\mathrm{Pt}_{52} \mathrm{Ru}_{48}$ & $\begin{array}{c}1.7 \pm 0.5 \\
\mathrm{~nm}\end{array}$ & $\begin{array}{c}\text { HOPG, Vulcan XC-72, } \\
20 \%\end{array}$ & Colloid & & $\begin{array}{c}\text { HRTEM, XPS, AFM } \\
\text { XRD }\end{array}$ & $\begin{array}{c}\text { Schmidt and et } \\
\text { al. } 1998\end{array}$ \\
\hline $\mathrm{Pt}_{\mathrm{x}} \mathrm{Ru}_{\mathrm{y}}$ & $2 \mathrm{~nm}$ & Vulcan XC-72 30\% & Colloid & $\mathrm{PtCl}_{2}, \mathrm{RuCl}_{3}$ & TEM, XRD, EDX & \begin{tabular}{|c|} 
Dubau and et al. \\
2003
\end{tabular} \\
\hline
\end{tabular}


Asia Pacific Journal of Energy and Environment, Volume 1, No 2 (2014)

\begin{tabular}{|c|c|c|c|c|c|c|}
\hline PtRu & $2.5-5 \mathrm{~nm}$ & Carbon cloth electrode & Microemulsion & $\mathrm{H}_{2} \mathrm{PtCl}_{6}, \mathrm{RuCl}_{3}$ & $\begin{array}{l}\text { XRD, XPS, TEM, } \\
\text { PCS, EDX }\end{array}$ & \begin{tabular}{|c|} 
Zhang and et al. \\
2003 \\
\end{tabular} \\
\hline Pt2Ru & $4-20 \mathrm{~nm}$ & Vulcan XC-72 40\% & Microemulsion & $\mathrm{H}_{2} \mathrm{PtCl}_{6}, \mathrm{RuCl}_{3}$ & TEM, XRD, XPS & $\begin{array}{l}\text { Liu and et al. } \\
2002\end{array}$ \\
\hline PtRu & $2-6 \mathrm{~nm}$ & Vulcan XC-72 & $\begin{array}{c}\text { Thermal decomposition } \\
\text { on Carbon }\end{array}$ & $\begin{array}{c}\mathrm{K}_{2} \mathrm{PtCl}_{4}, \mathrm{RuCl}_{2}\left(2,2^{\prime} \text {-bipyridine }\right) \\
\mathrm{Pt}_{2} \mathrm{Cl}_{4}\left(\mathrm{C}_{2} \mathrm{H}_{4}\right)_{2}, \mathrm{RuCl}_{3}\end{array}$ & $\begin{array}{l}\text { TEM, XRD, } \\
\text { EDS }\end{array}$ & $\begin{array}{l}\text { William and et } \\
\text { al. } 2003\end{array}$ \\
\hline $\mathrm{Pt}_{2} \mathrm{Ru}$ & $\begin{array}{c}2.5 \pm 0.5 \\
\mathrm{~nm}\end{array}$ & Vulcan XC-72 & $\begin{array}{l}\text { Decomposition } \\
\text { on carbon }\end{array}$ & $\mathrm{Pt}(\mathrm{CO}) x, \mathrm{Ru}_{3}(\mathrm{CO})_{12}$ & TEM, EDX & $\begin{array}{c}\text { Dickson and et } \\
\text { al. } 2002\end{array}$ \\
\hline $\mathrm{Pt}_{1.06} \mathrm{Ru}$ & $7 \mathrm{~nm}$ & $\begin{array}{l}\text { Graphitic carbon } \\
\text { nanofiber } 42 \%\end{array}$ & $\begin{array}{l}\text { Thermal decomposition of } \\
\text { bimetal complex }\end{array}$ & 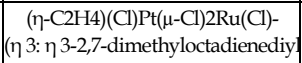 & $\begin{array}{l}\text { TEM, XRD, } \\
\text { EDS }\end{array}$ & $\begin{array}{c}\text { Steigerwalt and } \\
\text { et al. } 2001\end{array}$ \\
\hline PtxRuy & $2-5 \mathrm{~nm}$ & Vulcan XC-72 20\% & Reduction by formic acid & $\mathrm{H}_{2} \mathrm{PtCl}_{6}, \mathrm{RuCl}_{3}$ & XRD, EDX & $\begin{array}{l}\text { William and et } \\
\text { al. } 2002\end{array}$ \\
\hline PtRu & $2-3 \mathrm{~nm}$ & $\begin{array}{c}\text { Conducting polymer or } \\
\text { Vulcan XC-72 } 60 \%\end{array}$ & Reduction with LiBH4 in THF & $\mathrm{PtCl}_{2}$ and $\mathrm{RuCl}_{3}$ & $\begin{array}{l}\text { XRD, TEM, } \\
\text { SEM }\end{array}$ & $\begin{array}{c}\text { Choi and et al. } \\
2003 \\
\end{array}$ \\
\hline PtRu & $2-3 \mathrm{~nm}$ & $\begin{array}{c}\text { Carbonised colloidal } \\
\text { silica } 20 \%\end{array}$ & Borohydride reduction & & TEM & $\begin{array}{l}\text { Yu and et al. } \\
2002\end{array}$ \\
\hline Pt3Ru & $13.1 \mathrm{~nm}$ & $\begin{array}{l}\text { Mesoporous carbon } \\
\text { micro beads }\end{array}$ & Liquid-phase reduction & $\mathrm{H}_{2} \mathrm{PtCl}_{6}$ and $\mathrm{RuCl}_{3}$ & SEM, XRD & $\begin{array}{l}\text { Liu and et al. } \\
2002\end{array}$ \\
\hline PtRu & $\begin{array}{c}1.59 \pm 0.03 \\
\mathrm{~nm}\end{array}$ & Carbon nanotubes & $\begin{array}{l}\mathrm{H}_{2} \text { reduction at } \\
580^{\circ} \mathrm{C}\end{array}$ & $\mathrm{H}_{2} \mathrm{PtCl}_{6}$ and $\mathrm{RuCl}_{3}$ & SEM, TEM & $\begin{array}{c}\text { Che and et al. } \\
1998\end{array}$ \\
\hline PtRu & $2 \mathrm{~nm}$ & \begin{tabular}{|c|}
$\begin{array}{c}\text { Template carbonization } \\
\text { of poly pyrrole }\end{array}$ \\
\end{tabular} & $\begin{array}{l}\mathrm{H} 2 \text { reduction } \\
\text { at } 550 \mathrm{o} \mathrm{C}\end{array}$ & $\mathrm{H}_{2} \mathrm{PtCl}_{6}$ & $\begin{array}{c}\text { SEM, XPS, } \\
\text { HRTEM }\end{array}$ & $\begin{array}{c}\text { (Rajesh and et. al } \\
\text { 2002). }\end{array}$ \\
\hline
\end{tabular}

\section{IMPREGNATION METHOD}

The impregnation method is characterized by a deposition step of $\mathrm{Pt}$ or other metal precursors followed by a reduction step. Deposition means soaking up of a dissolved metal precursor, e.g. $\mathrm{PtCl}_{6}{ }^{2-}$ into the pores of a support, e.g. Vulcan 72 carbon, before reduction of the metal precursor to metal nanoparticles.

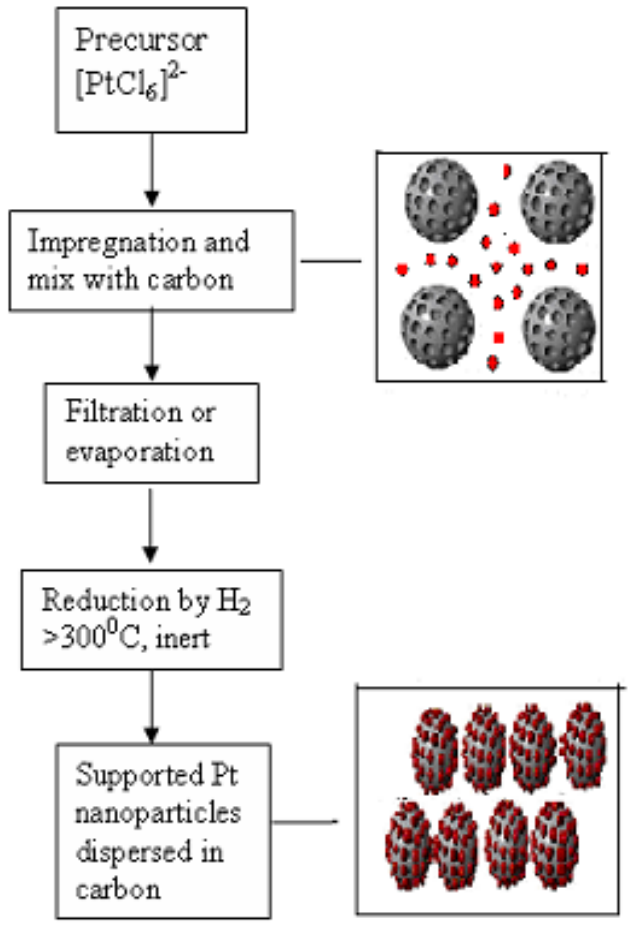

Fig. 3The impregnation procedure is shown schematically in the flow line
This method is simple and has been the most common method used for electrocatalyst preparation over the years. The reduction step can be chemical or electrochemical. The chemical reduction may be (liquid-phase reduction) (Park and et al. 2003) of the metallic catalysts slurry in solution by using reducing agents or gasphase reduction of the metallic particles impregnated carbon using a flowing $\mathrm{H}_{2}$ gas stream at a rather high temperature of about $250-600^{\circ} \mathrm{C}$ (Arico and et al. 2004). The common reducing chemicals are hydrazine, borohydride, formic acid, and hydrogen. Borohydrides are mostly used for the reduction. In the case of hydrogen, temperature elevation to above $300^{\circ} \mathrm{C}$ under an inert atmosphere is required. Control of the size and 
size distribution of particles depends on many factors. The morphology of the porous substrate and the pore size distribution will play a major role in terms of penetration and wetting of the precursor and also providing the confinement for nanoparticle growth. Reaction time and kinetics and mass-transfer of reducing agent will also affect the nucleation and growth of the nanoparticles.

\section{DraWBack OF ImPREgnATION Method}

The major drawback of the impregnation method is the lack of size control of metal particles except when the porous substrate has a narrow pore size distribution, e.g. in highly ordered mesoporous carbon. A distribution of particle sizes from nanometer to micron scale is commonly observed. Hydrogen can penetrate better into the micropores of the porous matrix. By the modification of surface of the support materials e.g. Vulcan 72 carbon, the activity of platinum toward methanol oxidation can be improved, In literature reports ( $\mathrm{Li}$ and et al. 2005), it has been found that the composite of platinum with hydrogen molybdenum bronze $(\mathrm{HxMoO} 3,0 \leq x \leq 2)$ can improve significantly the activity of platinum toward methanol oxidation, and several $\mathrm{Pt}-\mathrm{H}_{x} \mathrm{MoO}_{3}$ composite electrocatalysts have been prepared for methanol oxidation with the aim at the improvement of electrocatalytic activity of platinum and the reduction of platinum amount. Xingde Xiang and co workers (Xiang and et al. 2010) have developed a new composite of platinum with $\mathrm{H}_{x} \mathrm{MoO}_{3}$ by dispersing platinum nano-particles on the carbon modified with $\mathrm{H}_{x} \mathrm{MoO}_{3}$ and obtained a new electrocatalyst, dispersed platinum supported by hydrogen molybdenum bronze-modified carbon $\left(\mathrm{Pt} / \mathrm{H}_{\mathrm{x}} \mathrm{MoO}_{3}-\mathrm{C}\right)$, for methanol oxidation. The platinum supported with hydrogen molybdenum bronze-modified carbon exhibits better electrocatalytic activity toward methanol oxidation than the platinum supported with carbon without modification. The improved electrocatalytic activity is ascribed not only to the smaller particle size but also to the proton spillover effect between platinum and hydrogen molybdenum bronze. In addition to size, the shape of a nanocrystal may also provide another useful parameter to control when one needs to tailor the electronic, optical, magnetic, or chemical properties of a solid material.

\section{Colloidal Method}

It is the most common and powerful method to synthesize metal nanopartcles In this method metal colloids are taken in organic media then reduction of transition metal salt carried in the presence of stabilizing agent. The pt nanoparticles are synthesized using colloid techniques by the reduction of a platinum precursor $\left(\mathrm{H}_{2} \mathrm{PtCl}_{6}\right)$ in alcohol in the presence of a polymer capping agent to prevent aggregation (Humphrey and et al. 2007, Zhang and et al. 2007). As the particles nucleate and grow they are kept with a polymer that is porous enough to allow growth to various sizes from 1 to $8 \mathrm{~nm}$. The particle size can be controlled by the monomer concentration and with suitable changes of the growth parameters, it can be changed the shape of these particles from hexagonal to cubic, as well as to an intermediate shape called cuboctahedra, which is a cube with truncated vertices (Bratlie and et al. 2007) because catalytic reactivity depends on the size and the shape of the nanoparticles. For this reason the colloidal method is widely used for synthesizing metal nanoparticles with various size control. In the presence of a protective agent, such as surfactant molecules, the metal precursor is chemically reduced or reacted to form metal nanoparticles. A narrow size distribution is achieved as the colloidal metal nanoparticles 
are stabilized either by steric hindrance or by electrostatic charges. Colloidal metals can form in the organic medium (organosols) or aqueous medium (hydrosols).

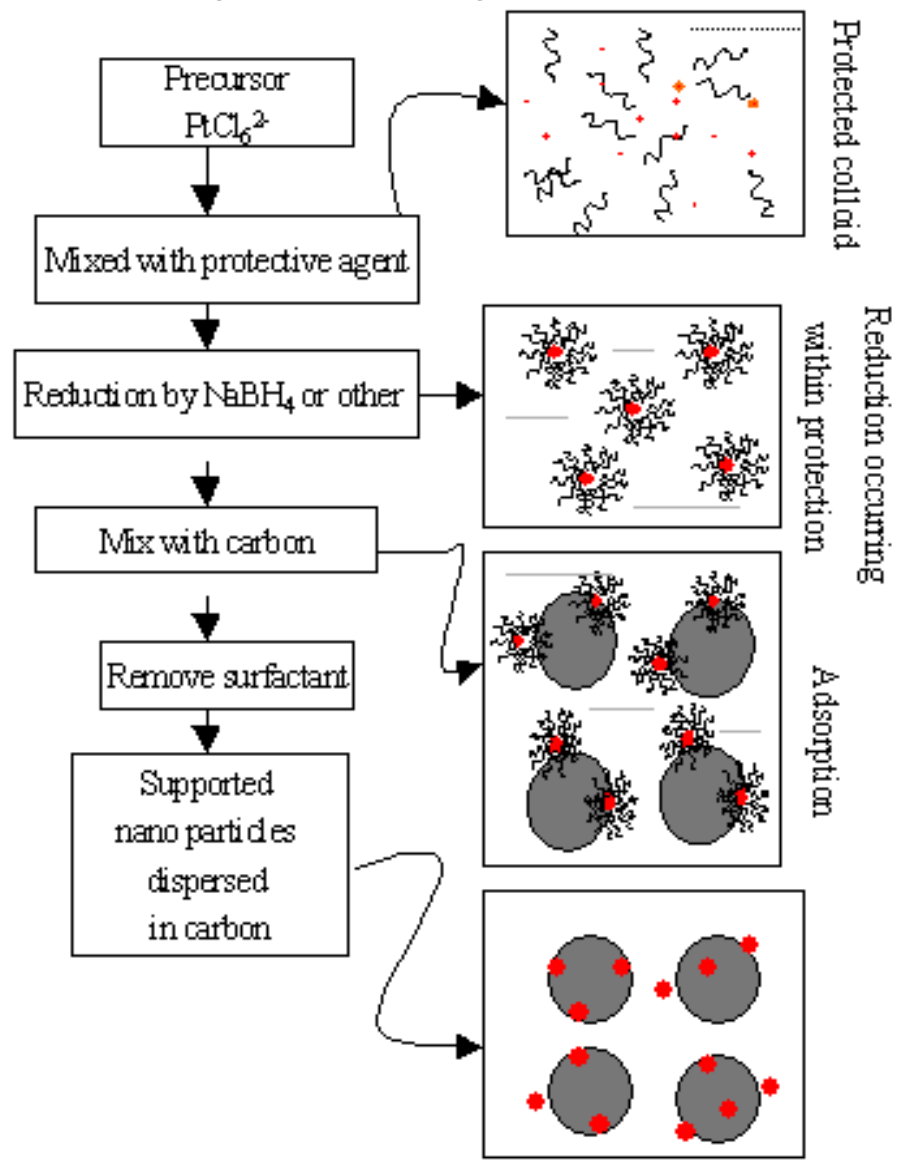

Fig .4 Colloidal method shown schematically the procedure in flow line
In the case of adsorbed ions or charged colloids, protection from merging into larger particles is provided by the electrostatic repulsion of like charges. On the other hand, coating the metal core with organic chain molecules can provide steric stabilization. Examples of common protecting ligands include $\mathrm{NR}_{4}{ }^{+}, \mathrm{PPh}_{3}, \mathrm{PVP}$, and PVA. Recently, this popular method has been widely used and PVP was introduced to stabilize the Pt nanoparticles in solution by preventing the particles from aggregating. In the presence of PVP, the reaction between alcohol and the metal precursor occurs. By FTIR spectroscopy, Bock and MacDougall (Bock and MacDougall $2003 \quad$ ) suggested that the colloidal metal nanoparticles may be protected by glycol, which serves as both a solvent and the protecting agent. The glycol can be removed by electro-oxidation during usage as an anode.

The glycol colloidal process is very attractive for large-scale synthesis of metal nanoparticles and this type of solution syntheses of $\mathrm{Pt}$ particles yield monodisperse samples with tunable size and shape. Catalyst materials that are prepared by the combination of the proper support and monodisperse particles have unprecedented uniformity, which is difficult to achieve with conventional catalyst synthetic methods. The effect of metal nanoparticle size on catalytic activity is better understood than the influence of nanoparticle shape on catalytic activity, since size control of crystallites has generally been easier to achieve than shape control.

Many studies on colloidal particles have focused on the control of particle sizes and their growth kinetics and have related particle size and catalytic activity. Moreover, research has shown that the degree of polymerization and the concentration of the stabilizing polymer influence the size distribution, stability, and catalytic activity of colloidal particles. For example, a recent study has shown that a higher ratio of capping material to 
metal produces smaller metal particles. Recently, the morphologies of Pt colloidal particles were studied by means of ultraviolet-visible spectrophotometry and transmission electron microscopy (TEM) (Duff and et al. 1998).

Introduction of foreign ions during solution phase synthesis of metal nanoparticles is a major parameter for controlling particle shape. A study on morphology changes of noble metal nanoparticles ( $\mathrm{Ag}, \mathrm{Pd}$, and $\mathrm{Pt}$ ) by adding various foreign ions (Long and et al. 2010). It was observed that chloride ions and oxygen in the reaction mixture preferentially dissolved twinned particles initially formed during reduction and led to selective formation of single crystalline products such as truncated tetrahedra and cuboctahedra. In another study by Chen et al. (Chen and et al. 2004), trace amounts of iron chloride slowed the reduction of $\mathrm{Pt}(\mathrm{II})$ species, inducing optimal anisotropic growth condition during a polyol process to form agglomerates of single-crystalline $\mathrm{Pt}$ nanowires rather than small $(<5 \mathrm{~nm})$ Pt crystallites which formed without iron chloride. The addition of large amounts of $\mathrm{NaNO}_{3}$ to a $\mathrm{Pt}$ salt solution led to the formation of branched nanostructures due to platinum nitrate formation, which alters the reduction kinetics of Pt. Addition of silver ions in a polyol synthesis of Pt nanoparticles results in lower nucleation temperatures, which favor anisotropic growth to form Pt multipods. Although several foreign ions have been reported to substantially affect particle morphologies, the exact mechanism has not been determined.

It is thought that selective adsorption of the additive ion on one or more crystal surfaces changes the selective growth rate of crystal faces leading to the change of shape. It was demonstrated the synthesis of Pt nanocrystals of well-defined shape (cubes, octahedra, and cuboctahedra) using the silver ions and poly (vinylpyrrolidone) (PVP) in solution (Song and et al. 2005).

However Pt nanoparticles of various sizes and shapes having the face-centered cubic structure are also synthesized by the alcohol reduction method. Alcohol also serves as both a solvent for dissolving metal precursors and surfactants and a reducing agent to produce Pt colloids. The synthesis of particulate pt metals by aqueous alcohol reduction of metal salts in the presence of polymeric stabilizer (or protector), in particular, has been reported to be an enabling technique toward a better control of the synthesized particle morphology and the aggregated structure. Hirai and co-workers (Hirai and et al. 1979) were the first to examine the catalytic activity and the formation mechanism of metal particles protected by polyvinyl alcohol or polyvinyl pyrrolidone (PVP) in methanol. Duff et al. (Duff et al. 1995) further confirmed that the aggregation of platinum particles was suppressed by a high $[\mathrm{PVP}] /[\mathrm{Pt}]$ ratio which in turn facilitated the dispersion of platinum sols so that the particles with a more uniform morphology become attainable. Chen and Akashi (Chen and Akashi 1997) synthesized colloidal platinum nanoparticles that were protected by poly (N-isopropylacrylamide) in ethanol/water mixtures by the reduction of $\left[\mathrm{PtCl}_{6}\right]^{2-}$. They reported that the protective polymer serves not only as a stabilizer, but also as a functional component conferring catalytic activity and selectivity. (Teranishi and et al. 1999) further revealed that the mean diameter of monodispersed Pt nanoparticles can be controlled from 1.9 to $3.3 \mathrm{~nm}$ by adjusting the kind of alcohol and the PVP concentration used in the sol process. The size of $\mathrm{Pt}$ particles with an ascending order, i.e., 1propanol $\backslash$ ethanol $\backslash$ methanol, was found when various alcohols were used. This suggests that the reduction rate of $\left[\mathrm{PtCl}_{6}\right]^{2-}$ ions in solution is critically important to the synthesized Pt particles. In addition, the synthesized particle size was found to decrease linearly with the alcohol concentration over the $[\mathrm{PVP}] /[\mathrm{Pt}]$ ratio range from 10 to 40. 
Though the colloidal method can provide a narrow size distribution of metal nanoparticles, the major drawback is the presence of the protecting agent, which may also hinder the catalytic function of the nanoparticles. The organic protecting shell can be removed by washing in an appropriate solvent or by decomposition at elevated temperature in an inert atmosphere. Before the removal of the protecting agent, adsorption into a protecting microporous catalyst support is necessary to prevent agglomeration into larger metal particles.

\section{Microemulsion Method}

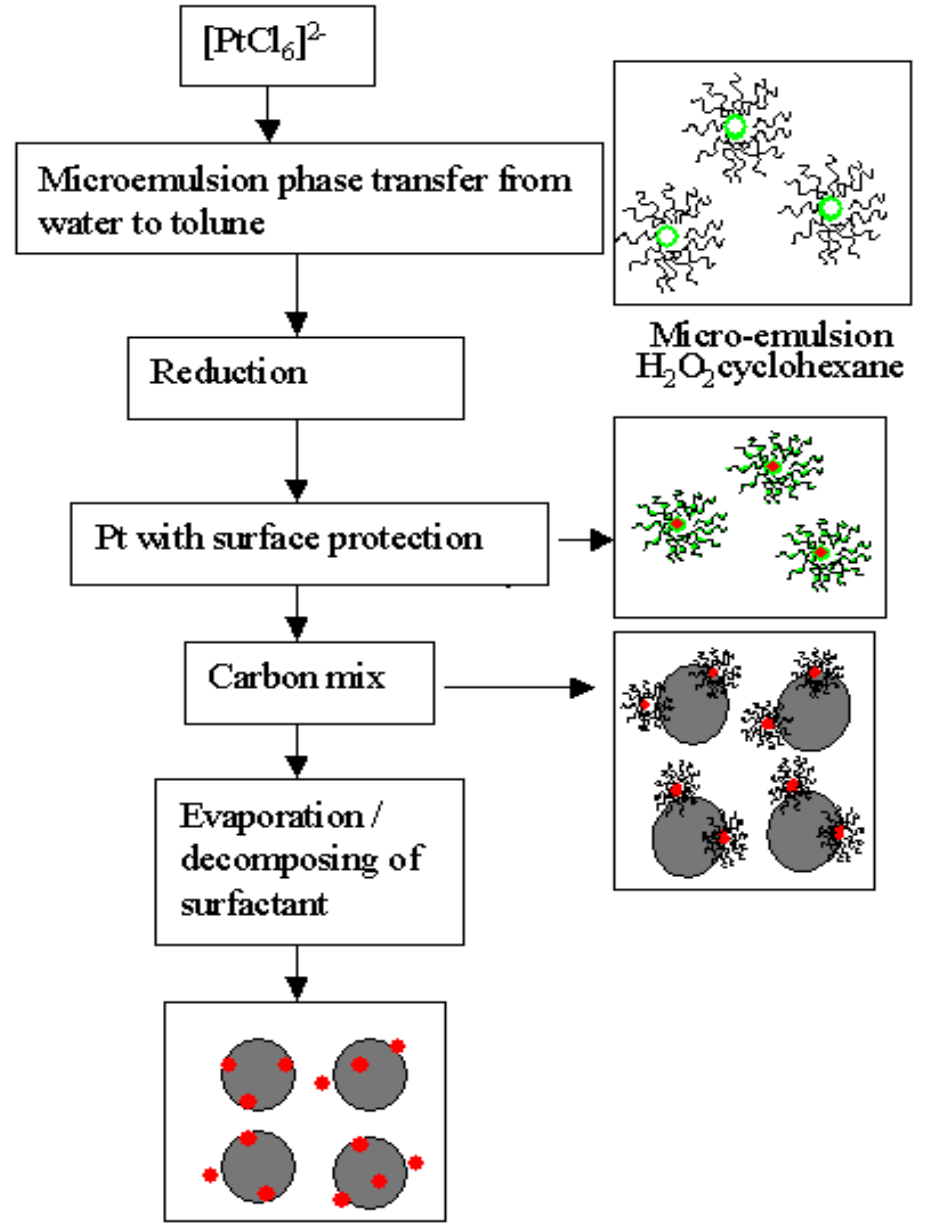

Fiz.5 The microentulsion method shown schematically the procedure in flow line
By this method a better control of particle size, shape, size distribution, and chemical composition are possible, Although a number of techniques have been used for producing nanoparticles which include gas evaporation sol-gel methods sputtering and co-precipitation. It is well documented in the scientific and patent literature that combining a transition metal element with platinum gives enhanced catalytic activities for reactions such as oxygen reduction in fuel cells and direct oxidation of methanol. It is, however, difficult to control the size and size distribution, and gain a consistent nanoscopic chemical composition with these preparation techniques.

Microemulsion is a tiny drop of precursor containing liquid engulfed by surfactant molecules. This microemulsion is uniformly dispersed in a continuous liquid phase, which is immiscible to the precursor containing liquid phase. The chemical reaction is confined within a microemulsion. The size of the microemulsion is of the order of a few nanometers to hundreds of nanometers and is determined by the balance of surface free energy mediated by the surfactant molecules and the free energy difference arising from the immiscibility of the two liquid phases. Normally, the dispersed liquid phase is oil and water forms the continuous medium. The reverse microemulsion is the water-in-oil 
microemulsion can be possible. A co-surfactant is sometimes added to modify the size of the microemulsion. Supercritical carbon dioxide has also been used as the continuous medium for the microemulsion method and gives additional ease in separation of the nanoparticle from the medium. So the preparation of nanoparticles with water-in-oil (w/o) microemulsion has attracted increasing attention but systematic investigation is warranted (Ohde and et al. 2001). It has reported an alternative route to synthesize dodecanethiol-stabilized Pt NPs, with narrow and controllable size distribution, by a two-phase route by (Castro and et al. 2009). The synthesis was based on a phase-transfer (water to toluene) of $\left[\mathrm{PtCl}_{6}\right]^{2-}$ followed by reduction and surface protection with dodecanethiol (DT). Since chemical steps are conducted within the microemulsion, which serves as a micro- or nano-scale reactor, a narrow particle size distribution can be obtained accordingly. The introduction of a reducing agent, e.g. hydrazine, into the miroemulsion is achieved by stirring and the reaction time is in the order of minutes. The size and distribution of the nanoparticle can be further controlled and improved by a twomicroemulsion method with the reducing agent also confined in a separate emulsion. The two microemulsion technique has been applied to synthesize mixed metal nanoparticles of $\mathrm{Pt}-\mathrm{Co}$ and $\mathrm{Pt}-\mathrm{Ru}$ (Zhang and Chan 2002). The final composition of the mixed metal nanoparticles has been easily controlled by the ratio of the metal precursors solutions. Various parameters that control the size of particles in the microemulsion method such as water to surfactant ratio, the amount of surfactants, the concentration of precursor solution and temperature etc. After the reduction step, nanoparticles are protected from agglomeration by the surfactant molecules. Similarly to the colloidal method where protecting agents are used, they should be adsorbed onto a porous support before the surfactant molecules are removed. Nevertheless, the microemulsion method requires the use of costly surfactant molecules with extra washing steps and may not be economical for a large-scale synthesis.

\section{EfFEct Of Temperature on Nanoparticle's Size}

The nanoparticle size is one of the important factors to control the unique properties of nanomaterials. Usually, the smaller the nanoparticle size is, the more prominent the unique properties are. Therefore, people attempt to control the size of nanoparticles as small as possible in sample preparation. However, the nanoparticle size depends not only on the sample preparation, but also on the applied environment of nanomaterials including temperature and even radiation (Kluth and et al. 2006). It is well known that the nanoparticle size will become larger with temperature increasing for most free nanomaterials.

\section{CONCLUSION AND OUTLOOK}

Platinum stands as one of the most important metals for several industrial applications. We have reviewed the chemical synthesis process of platinum nanoparticles from the last decade. In the past few years, considerable progress has been made in the synthesis of monodisperse and well-defined structured pt nanoparticles with sizes ranging from 1.2 to several nm. From the work detailed in this review, it is clear that the chemical method is relatively easy and inexpensive, by microemulsion process pt nanoparticles with better control of particle size, shape, size distribution, and chemical composition can be produce. The outlook of such platinum nanoparticles is very promising because these materials will find many important applications including as a catalyst in Fuel cell, Bio sensor,etc.In fuel cell platinum nanoparticles are used in reformers for the production of hydrogen from solid, liquid, or gaseous energy carriers. 


\section{REFERENCES}

Arico A.S, Baglio V., Modica E, Di Blasi A, Antonucci V, (2004) Performance of DMFC anodes with ultralow Pt loading, Electrochem Commun. Volume:6, p:164.

Belapurkar A. D., Kapoor S., Kulshreshtha S.K. and Mittal J. P., (2001) Radiolytic preparation and catalytic properties of platinum nanoparticles, Mater. Res. Bull., Volume:36, p.145.

Bock C. and MacDougall B., (2003) Proceedings of the Knowledge Foundation's 4th International Conference on Nanostructured Materials, Miami, , ed. S. Pan, Knowledge Press, Brookline, MA.

Bratlie K. M, Lee H, Komvopoulos K, Yang P, Somorjai G.A, (2007) Platinum Nanoparticle Shape Effects on Benzene Hydrogenation Selectivity, Nano Letters, Volume:7, page: 3097.

Castro E. G., Salvatierra R.V., Oliveira M. M., Schreiner W. H., Zarbin A. J. G. (2009), International conference on Advance Materials.

Chan K.Y., Ding J., Ren J., Cheng S. and Tsang K. Y.; (2004) Supported Mixed Metal Nanoparticles for Fuel Cell Electrode J. Mater. Chem, volume:14, p.:505.

Che G., Lakshmi B. B., Fisher E. R. and Martin C. R., (1998) Carbon nanotubule membranes for electrochemical energy storage and production, Nature, Volume: 393, p.: 346.

Chen C.W, Akashi M. (1997) Synthesis, characterization, and catalytic properties of colloidal platinum nanoparticles protected by poly ( $\mathrm{N}$-isopropylacrylamide). Langmuir Volume:13, p.:6465-6472.

Chen G. Y., Delafuente D. A., Sarangapan S. i and Mallouk T. E., (2001) Combinatorial discovery of bifunctional oxygen reduction - water oxidation electrocatalysts for regenerative fuel cells, Catal. Today,Volume: 67,p.: 341.

Chen J., Herricks T., Geissler M. and Xia Y., (2004) Single-Crystal Nanowires of Platinum Can Be Synthesized by Controlling the Reaction Rate of a Polyol Process, J. Am. Chem. Soc. Volume:126, p.: 10854.

Chen W., Zhang J., and Cai W., (2003) Sonochemical preparation of $\mathrm{Au}, \mathrm{Ag}, \mathrm{Pd} / \mathrm{SiO} 2$ mesoporous nanocomposites, Scr. Mater., volume: 48, p.:1061.

Choi J. H., Park K. W., Lee H. K., Kim Y. M., Lee J. S. and Sung Y. E., (2003) Nano-composite of PtRu alloy electrocatalyst and electronically conducting polymer for use as the anode in a direct methanol fuel cell, Electrochim. Acta, Volume:48, p.:2781.

Dickson A. J., Carrette L. P. L., Collins J. A., Friedrich K. A. and Stimming U., (2002), Preparation of a $\mathrm{Pt}$ 門 $\mathrm{Ru} / \mathrm{C}$ catalyst from carbonyl complexes for fuel cell applications, Electrochim. Acta, , Volume:47,p.: 3733.

Dubau L., Coutanceau C., Garnier E., Leger J. M. and Lamy C., (2003), Electrooxidation of methanol at platinum-ruthenium catalysts prepared from colloidal precursors: Atomic composition and temperature effects, J. Appl. Electrochem., Volume: 33, p.419-429.

Duff D. G., Edwards P. P., Johnson B. F. G., (1995) Formation of a Polymer-Protected Platinum Sol: A New Understanding of the Parameters Controlling Morphology, J. Phys. Chem. Volume: 99, p.15934.

Friedrich K. A., Geyzers K. P., Dickinson A. J. and Stimming U., (2002) Fundamental aspects in electrocatalysis: from the reactivity of single-crystals to fuel cell electrocatalysts, J. Electroanal. Chem., Volume: 524-525, page 261.

Ghavale N., Dey S., Jain V. K and Tewari R. (2009) 2-Methoxycycloocta-1,5-dienyl platinum complexes as precursors for platinum nanoparticles, Bull. Mater. Sci., Volume: 32, No. 1, p. 15-18.

Gratiet B. L., Remita H., Picq G. and Delcourt M. O., (1996) CO-Stabilized Supported Pt Catalysts for Fuel Cells: Radiolytic Synthesis, J. Catal., Volume:164, page: 36.

Hirai H (1979) Formation and catalytic functionality of synthetic polymer noble metal colloid. J Macromol Sci-Chem, Volume: A13, p.:633-649.

Humphrey S.M, Grass M.E, Habas S.E, Niesz K, Somorjai G.A, Tilley T.D, (2007) Rhodium Nanoparticles from Cluster Seeds: Control of Size and Shape by Precursor Addition Rate, Nano Letters, Volume: 7, page :785.

Jiang J., and Kucernak A. , (2003) Electrooxidation of small organic molecules on mesoporous precious metal catalysts: II: CO and methanol on platinum-ruthenium alloy, J. Electroanal. Chem., Volume:543, p.187.

Joo S. H., Choi S. J., Oh I., Kwak J., Liu Z., Terassaki O. and Ryoo R.,(2001) Ordered nanoporous arrays of carbon supporting high dispersions of platinum nanoparticles, Nature, Volume: 412,p.: 169.

Kim Y.-G, Oh S.-K. and Crooks R.M., (2004) Preparation and Characterization of 1-2 nm Dendrimer-Encapsulated Gold Nanoparticles Having Very Narrow Size Distributions, Chem. Mater. Volume: 16, p.:167.

Kluth P., Johannessen B., Cookson D.J., Foran G.J., Ridgway M.C., (2006) SAXS and EXAFS studies of ion beam synthesized Au nanocrystals, Nucl. Inst. Meth. in Phys. Res. B Volume:246,p. 30.

Knecht M.R, Wright D.W (2004) Dendrimer-Mediated Formation of Multicomponent Nanospheres, Chem Mater Volume:16, p.:4890. 
Ledesma-Garci J, Escalante Garci I. L, Rodri F. J, Chapman T. W, Godinez L. A (2008) Immobilization of dendrimer-encapsulated platinum nanoparticles on pretreated carbon-fiber surfaces and their application for oxygen reduction. J Appl Electrochem Volume: 38, p.:515.

Li L.H. \& Zhang W.D, (2008) Preparation of carbon nanotubes supported platinum nanoparticles by an organic colloidal process for nonenzymatic glucose sensing, Microchim Acta Volume:163,p.:305-311.

Li W., Liang C., Zhou W., Qiu J., Zhou Z., Sun G. and Xin Q., (2003)Preparation and Characterization of Multiwalled Carbon Nanotube-Supported Platinum for Cathode Catalysts of Direct Methanol Fuel Cells, J. Phys. Chem. B, Volume: 107,p.: 6292.

Li W.S, Lu J, Du JH, Lu D.S, Chen H.Y, Li H, Wu Y.M. (2005) Electrocatalytic oxidation of methanol on polyaniline-stabilized Pt-HxMoO3 in sulfuric acid solution, Electrochem Commun Volume:7, p.:406.

Li, X. and Hsing I.-M., (2006) Surfactant-stabilized PtRu colloidal catalysts with good control of composition and size for methanol oxidation, Electrochim. Acta, volume: 52, p. 1358.

Liu Y. C., Qiu X. P., Huang Y. Q. and Zhu W. T., (2002) Methanol electro-oxidation on mesocarbon microbead supported Pt catalysts, Carbon, Volume: 40, p.: 2375.

Liu Y. C., Qiu X. P., Huang Y. Q. and Zhu W. T., (2002), Mesocarbon microbeads supported Pt-Ru catalysts for electrochemical oxidation of methanol, J. Power Sources, Volume:111, p.160.

Liu Z., Lee J., Han M., Chen W. and Gan L., (2002) Synthesis and characterization of PtRu/C catalysts from microemulsions and emulsions, J. Mater. Chem.,Volume: 12,p.: 2453.

Long N. V., Chien N.D., Hayakawa T., Hirata H., Lakshminarayana G. and Nogami M. (2010) The synthesis and characterization of platinum nanoparticles: a method of controlling the size and morphology, , Nanotechnology Volume:21, p.: 035605.

Maiyalagan T., (2009) Pt-Ru nanoparticles supported PAMAM dendrimer functionalized carbon nanofiber composite catalysts and their application to methanol oxidation, J Solid State Electrochem, volume:13, Issue:10, p.:1561.

Mu X.-D., Evans D. G., and Kou Y., (2004), A General Method for Preparation of PVP-Stabilized Noble Metal Nanoparticles in Room Temperature Ionic Liquids Catalysis Letters Volume: 97, Nos. 3-4, September p.151-154.

Ohde, Hunt F. and Wai C. M., (2001), Synthesis of Silver and Copper Nanoparticles in a Water-inSupercritical-Carbon Dioxide Microemulsion, Chem. Mater., Volume:13,p. 4130.

Park K. W., Choi J. H., Kwon B. K., Lee S. A., and Sung Y. E., (2002) Chemical and Electronic Effects of Ni in $\mathrm{Pt} / \mathrm{Ni}$ and $\mathrm{Pt} / \mathrm{Ru} / \mathrm{Ni}$ Alloy Nanoparticles in Methanol Electrooxidation, J. Phys. Chem. B, Volume:106, p.1869.

Park S.J, Jung H.J, Nah C.W (2003) Adsorption Properties of Fuel-Cell Electrode Produced from Activated Carbon Fibers in Three Phase Distribution, Polymer (Korea) Volume:27, p.:46.

Rajesh B., Karthik V., Karthikeyan S., Thampi K. R., Bonard J. M. and Viswanathan B., (2002) Pt-WO3 supported on carbon nanotubes as possible anodes for direct methanol fuel cells, Fuel, Volume: 81, p.2177.

Rioux R.M., Song H., Grass M., Habas S., Niesz K., Hoefelmeyer J.D., Yang P., and Somorjai G.A., (2006) Monodisperse platinum nanoparticles of well-defined shape: synthesis, characterization, catalytic properties and future prospects, Topics in Catalysis Volume: 39, Nos. 3-4, October, p. 167-174.

Schmidt T. J., Noeske M., Gasteiger H. A., Behm R. J., Britz P. and . Bo"nnemann H, (1998), PtRu Alloy Colloids as Precursors for Fuel Cell Catalysts: A Combined XPS, AFM, HRTEM, and RDE Study J. Electrochem. Soc., Volume:145, p.: 925.

Song H., Kim F., Connor S., Somorjai G.A. and Yang P., (2005) Pt Nanocrystals: Shape Control and Langmuir-Blodgett Monolayer Formation, J. Phys. Chem. B Volume:109, p.: 188.

Steigerwalt S., Deluga A., Cliffel E. and Lukehart C. M., (2001) A Pt-Ru/Graphitic Carbon Nanofiber Nanocomposite Exhibiting High Relative Performance as a Direct-Methanol Fuel Cell Anode Catalyst, J. Phys. Chem. B, Volume: 105, p.:8097-8101.

Takasu Y., Fujiwara T., Murakami Y., Sasaki K., Oguri M., Asaki T. and Sugimoto W., (2000), Effect of Structure of Carbon- Supported PtRu Electrocatalysts on the Electrochemical Oxidation of Methanol, J. Electrochem. Soc.,Volume:147, p.:4421.

Teranishi T, Hosoe M, Tanaka T, Miyake M (1999) Size control of monodispersed Pt nanoparticles and their 2d organization by electrophoretic deposition. J Phys Chem B, Volume:103:3818-3827.

Umeda M., Kokubo M., Mohamedi M. and Uchida I.,( 2003) Porous-microelectrode study on Pt/C catalysts for methanol electrooxidation, Electrochim. Acta, Volume:48, p.1367.

Vijayaraghavan G, Stevenson KJ (2007) Synergistic Assembly of Dendrimer-Templated Platinum Catalysts on Nitrogen-Doped Carbon Nanotube Electrodes for Oxygen Reduction, Langmuir Volume:23, p.:5279. 
Wang S.R., Tseng W. J., (2009) Aggregate structure and crystallite size of platinum nanoparticles synthesized by ethanol reduction, J. Nanopart. Res. Volume:11, page:947.

Warren S. C., Messina L. C., Slaughter L. S., Kamperman M., Zhou Q., Gruner S. M., . DiSalvo F. J, Wiesner U., (2008) Ordered Mesoporous Materials from Metal Nanoparticle-Block Copolymer Self-Assembly, Science Volume:320, p. 1748-1752.1

William D. K., James D. C., Oliver J. M., Deborah L. B., Edward A. K., Krzysztof C. K., Stuart R. S. and Lukehart C. M., (2003) Pt-Ru and Pt-Ru-P/Carbon Nanocomposites: Synthesis, Characterization, and Unexpected Performance as Direct Methanol Fuel Cell (DMFC) Anode Catalysts, J. Phys. Chem. B, Volume: 107,p. 5467.

William H., Valdecir A. and Gonzalez R., (2002) Methanol electro-oxidation on gas diffusion electrodes prepared with Pt理Ru/C catalysts, Electrochim. Acta, Volume:47, p.: 3715.

Xiang X., Li W., Zhou Z., Fu Z., Lei J. and Lin Y., (2010) Dispersed platinum supported by hydrogen molybdenum bronze-modified carbon as electrocatalyst for methanol oxidation, J Solid State Electrochem, Volume:14, p.: 903.

Yang B., Lu Q., Wang Y., Zhuang L., Liu P., Wang J. and Wang R., (2003) Simple and Low-Cost Preparation Method for Highly Dispersed PtRu/C Catalysts, Chem. Mater., , Volume:15, p.:3552.

Ye H, and Crooks R. M. (2007), Effect of Elemental Composition of PtPd Bimetallic Nanoparticles Containing an Average of 180 Atoms on the Kinetics of the Electrochemical Oxygen Reduction Reaction, J. Am. Chem. Soc. Volume:129,p.:362.

Ye X. R., Lin Y. and Wai C. M., (2003) Decorating catalytic palladium nanoparticles on carbon nanotubes in supercritical carbon dioxide, Chem. Commun.,p. 642.

Yu J. S., Kang S., Yoon S. B. and Chai G., (2002) Fabrication of Ordered Uniform Porous Carbon Networks and Their Application to a Catalyst Supporter, J. Am. Chem. Soc., Volume:124, p.: 9382.

Yu J. S., Kang S., Yoon S. B. and Chai G., (2002) Fabrication of Ordered Uniform Porous Carbon Networks and Their Application to a Catalyst Supporter, J. Am. Chem. Soc., ,Volume:124, p.: 9382.

Yu R., Chen L., Liu Q., Lin J., Tan K. L., S. Ng C., Chan H. S. O., Xu G.-Q. and Hor T. S. A., (1998) Platinum Deposition on Carbon Nanotubes via Chemical Modification, Chem. Mater., Volume: 10,p. 718.

Zhang X. and Chan K. Y., (2002), Microemulsion synthesis and electrocatalytic properties of platinumcobalt nanoparticles, J. Mater. Chem., Volume:12,p.:1203.

Zhang X. and Chan K. Y., (2003) Water-in-Oil Microemulsion Synthesis of Platinum-Ruthenium Nanoparticles, Their Characterization and Electrocatalytic Properties, Chem. Mater., Volume:15, p.:451.

Zhang Y, Grass M.E, Habas S.E, Tao F, Zhang T, Yang P, Somorjai G.A, (2007) One-step Polyol Synthesis and Langmuir-Blodgett Monolayer Formation of Size-tunable Monodisperse Rhodium Nanocrystals with Catalytically Active (111) Surface Structures, J Phys Chem C, Volume:111, page:12243.

Zhou Z., Wang S., Zhou W., Wang G., Jiang L., Li W., Song S., Liu J., Sun G. and Xin Q., (2003) Novel synthesis of highly active Pt/C cathode electrocatalyst for direct methanol fuel cell, Chem. Commun.,, p.: 394;

Zoval J. V., Lee J., Gorer S., and Penner R. M, (1998) Electrochemical Preparation of Platinum Nanocrystallites with Size Selectivity on Basal Plane Oriented Graphite Surfaces, J. Phys. Chem. B, , volume:102, Issue:7, p.1166.

\section{CALl fOR PAPER}

ABC Journal of Advanced research (ABC-JAR) is an open-access, peer-reviewed multidisciplinary journal which seeks articles from any discipline of education. ABC-JAR features reports on current developments in advanced research as well as on related discipline issues. The digital online version is published by ABC-JAR home, ABC USA and the hard copy (print) version is published by $A B C$, Bangladesh. Web: www.abcjar.us
Engineering International (EI) is a peer-reviewed multi-disciplinary international journal devoted to academic advanced research from all aspects of engineering arena. It specializes in the publication of comparative thematic issues as well as individual research articles, review essays, and book reviews. Engineering International is fully and freely accessible on line. Web: www.j-ei.us 


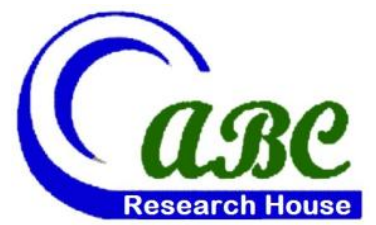

- Rd 4, Shyamoli, Dhaka-1207, Bangladesh

- Off Pantai Dalam, Kuala Lampur, Malaysia

- 3900 Woodhue Place, Alexandria, VA 22309, USA

www.abcreorg.weebly.com / www.abcjournals.net

Asian Business Consortium (ABC) is a multi-disciplinary research, training, publishing, digital library supporting and service house. Though founded in 2010 as the Business and Computing organization of Asia, it was reconstituted as the ABC in 2011. It has been working for creating and nurturing talents in USA, Malaysia and Bangladesh since its inception. As ABC is going global, it intends to open chapters in Australia, Germany, Japan, Pakistan, and other Asian countries in near future. The objectives of consortium are solely centered round the welfare and humane attitude of the founders who enthusiastically took up this noble cause and materialized it with a view to promote research and educational activities for the encouragement of scholars to develop their knowledge, to publish their analysis oriented scientific researches in international Journals, books, the task of organizing workshops, seminars, conferences, training, personality development programs and allied services.

In addition to research activities, $A B C$ provides a good number of scholarships to the poor and meritorious students at various levels of education throughout the world. It plays an important role in the field of research by funding research projects and publishing the research papers. This consortium will unquestionably become the mouth-piece of the dark horses and unacknowledged scholar whose endowed and commendable contributions shall be provided an outlet keeping in mind the greater good of the larger society of the world.

$\mathrm{ABC}$ runs the following international referred journals for creating a platform to share the thoughts of professionals, scholars and academicians throughout the world.

\section{ABC Publications (ABC Journals)}

- Asian Accounting and Auditing Advancement (4A Journal)

- Asian Business Review (ABR)

- Asian Journal of Applied Sciences and Engineering (AJASE)

- Global Disclosure of Economics and Business (GDEB)

- $\quad$ ABC Journal of Advanced Research (ABC-JAR)

- International Journal of Reciprocal Symmetry and Theoretical Physics (IJRSTP)

- American Journal of Trade and Policy (AJTP)

- Asian Journal of Humanity, Art and Literature (AJHAL)

- Malaysian Journal of Medical and Biological Research (MJMBR)

- Asia Pacific Journal of Energy and Environment (APJEE)

- $\quad$ Engineering International (EI)

- $\quad$ ABC Research Alert (Online)

Each journal home page provides specific information for potential authors and subscribers. Open access policy, the quick review process, rich editorial boards and quality publications have already made $A B C$ Journals unique. ABC Journals are published under the direct supervisions of renowned academicians of the world.

Collaboration in Conference: $A B C$ considers high-quality conference papers for publication. Please contact us for detailed information.

Collaboration in Publishing: If you like to start writing a book, propose a new journal or advertise in $\mathrm{ABC}$ journals, please feel free to contact us. 